\title{
Integrated Experimental and Thermodynamic Modeling Investigation of Phase Equilibria in the $\mathrm{PbO}-\mathrm{MgO}-\mathrm{SiO}_{2}$ System in Air
}

\author{
HAMED ABDEYAZDAN, MAKSYM SHEVCHENKO, PETER C. HAYES, \\ and EVGUENI JAK
}

\begin{abstract}
Magnesium oxide-based refractory materials are used industrially to contain the chemically aggressive slags present in lead smelting systems. In the present study an integrated experimental and thermodynamic modeling approach was taken to provide fundamental information on the chemical reactions taking place in these systems. New experimental phase equilibria and liquidus data were obtained for the $\mathrm{PbO}-\mathrm{MgO}-\mathrm{SiO}_{2}$ system in air in the temperature range 750 ${ }^{\circ} \mathrm{C}$ to $1740{ }^{\circ} \mathrm{C}$. In the $\mathrm{MgO}-\mathrm{SiO}_{2}$ binary, new experimental results were obtained at $1550{ }^{\circ} \mathrm{C}$ to $1740{ }^{\circ} \mathrm{C}$ and compared to the available thermodynamic data in the literature. The experiments were carried out using the high-temperature equilibration of oxide powder mixtures followed by rapid quenching of the samples. Electron probe X-ray microanalysis (EPMA) was used to determine the compositions of the solid and liquid phases present at equilibrium conditions. Phase equilibria and liquidus isotherms in the cristobalite and tridymite $\left(\mathrm{SiO}_{2}\right)$, pyroxene (protoenstatite $\mathrm{MgSiO}_{3}$ ), olivine (forsterite $\mathrm{Mg}_{2} \mathrm{SiO}_{4}$ ), barysilite $\left(\mathrm{Pb}_{8} \mathrm{MgSi}_{6} \mathrm{O}_{21}\right)$, massicot $(\mathrm{PbO}$ ) and periclase $(\mathrm{MgO})$ primary phase fields were measured, and the extent of the high-silica two-liquid immiscibility gap in equilibrium with cristobalite was determined. The experimental results were used to optimize the parameters in a thermodynamic database that was subsequently used to describe this multi-component, multi-phase system and predict the liquidus for the $\mathrm{PbO}-\mathrm{MgO}-\mathrm{SiO}_{2}$ system. The new data were used to characterize the chemical interactions of magnesia-based refractory with $\mathrm{PbO}-\mathrm{MgO}-\mathrm{SiO}_{2}$ slags.
\end{abstract}

https://doi.org/10.1007/s11663-022-02440-6

(C) The Author(s) 2022

\section{INTRODUCTION}

REFRACTORY materials play an important role in high-temperature metallurgical processing by providing the means of containment of heat and materials under chemically aggressive conditions. Refractory service life in these high-temperature reactors has been shown to be influenced by chemical, mechanical and thermal factors. $^{[1,2]}$ Chemical reactions between slag and refractories lead to dissolution and weakening of the refractory material. ${ }^{[3-7]}$ These chemical reactions are made more complex by not only the presence of several different phases in the refractory materials but also the formation of new compounds. While the significance of the

HAMED ABDEYAZDAN, MAKSYM SHEVCHENKO, PETER C. HAYES, and EVGUENI JAK are with the School of Chemical Engineering, Pyrometallurgy Innovation Centre (PYROSEARCH), The University of Queensland, Brisbane, QLD 4072, Australia. Contact e-mail: h.abdeyazdan@uq.edu.au

Manuscript submitted August 17, 2021; accepted January 8, 2022.

Article published online February 8, 2022. slag-refractory interactions is recognized, fundamental information on the phase equilibria is required to more fully understand why these reactions are taking place and to be able to predict and interpret the reaction sequences. Phase diagrams have been shown to be particularly useful in understanding the relative stabilities of refractory materials and their interactions with slags in complex chemical systems. ${ }^{[8-12]}$

Magnesia-chromia refractories are commonly used in the linings of lead smelting and refining pyrometallurgical reactors ${ }^{[13-16]}$; however, relatively little information is available on the fundamental reactions taking place in these systems. Magnesia grains in the refractories are susceptible to chemical attack by low melting temperature silica-containing slags present in metallurgical smelting. In addition, previous studies ${ }^{[12,17]}$ have shown that the presence of silicate-containing phases in the original magnesia-based refractory materials can lead to selective grain boundary attack of the refractory materials. The $\mathrm{PbO}-\mathrm{SiO}_{2}$ binary system contains the primary phase fields of cristobalite, tridymite $\left(\mathrm{SiO}_{2}\right), \mathrm{PbSiO}_{3}$, $\mathrm{Pb}_{2} \mathrm{SiO}_{4}, \mathrm{~Pb}_{11} \mathrm{Si}_{3} \mathrm{O}_{17}, \mathrm{~Pb}_{5} \mathrm{SiO}_{7}$ and $\mathrm{PbO} \cdot{ }^{[18-24]}$ Following a critical analysis of the experimental and 
thermodynamic data available on the $\mathrm{PbO}-\mathrm{SiO}_{2}$ binary and further experimental measurements, Jak et al. ${ }^{[22]}$ described this system using an optimized thermodynamic database. Subsequent experimental studies by Shevchenko and $\mathrm{Jak}^{[23]}$ have demonstrated that there is, in fact, no liquid immiscibility in the $\mathrm{PbO}-\mathrm{SiO}_{2}$ binary in the high-silica region of the $\mathrm{PbO}-\mathrm{SiO}_{2}$ binary, and the liquidus in the cristobalite/tridymite primary phase field is in agreement with that previously reported by Hirota. ${ }^{[24]}$

The $\mathrm{MgO}-\mathrm{SiO}_{2}$ binary system contains the primary phase fields of periclase $(\mathrm{MgO})$, olivine (forsterite $\mathrm{Mg}_{2} \mathrm{SiO}_{4}$ ), pyroxene (protoenstatite $\mathrm{MgSiO}_{3}$ ) and cristobalite $\left(\mathrm{SiO}_{2}\right)$, with liquid-liquid immiscibility in the high silica region. Experimental phase equilibria data for this system were reported by ${ }^{[25-29]}$ and the system described by thermodynamic models. ${ }^{[30,31]}$

The phases present in sub-solidus conditions in the $\mathrm{PbO}-\mathrm{MgO}-\mathrm{SiO}_{2}$ ternary system were reported by Argyle et al. ${ }^{[32]}$ The experimental study by Chen et al. ${ }^{[33]}$ provided information on the liquidus and phase relations in the $\mathrm{PbO}-\mathrm{MgO}-\mathrm{SiO}_{2}$ system in the low- $\mathrm{MgO}$ region of the system for temperatures in the range of 700 ${ }^{\circ} \mathrm{C}$ to $1400{ }^{\circ} \mathrm{C}$, principally in the olivine (forsterite, $\mathrm{Mg}_{2} \mathrm{SiO}_{4}$ ) primary phase field. It was shown that there is no solid solution of $\mathrm{PbO}$ in the binary compounds of $\mathrm{SiO}_{2}$ and $\mathrm{MgO}$ or $\mathrm{MgO}$ in the boundary compounds of $\mathrm{SiO}_{2}$ and $\mathrm{PbO}$; the primary phase fields of olivine (forsterite, $\mathrm{Mg}_{2} \mathrm{SiO}_{4}$ ) and $\mathrm{Mg}-\mathrm{Pb}$ barysilite $\left(\mathrm{Pb}_{8} \mathrm{MgSi}_{6} \mathrm{O}_{21}\right)$ were stable over a wide range of compositions. No phase equilibria data on the $\mathrm{PbO}-\mathrm{MgO}-$ $\mathrm{SiO}_{2}$ ternary have been reported in the literature for compositions $<20 \mathrm{~mol}$ pct $\mathrm{SiO}_{2}$, for the cristobalite/ tridymite phase fields or for the $\mathrm{PbO}-\mathrm{MgO}$ binary system. The activities of $\mathrm{PbO}$ in ternary $\mathrm{PbO}-\mathrm{MgO}-$ $\mathrm{SiO}_{2}$ slags were reported for temperatures in the range $1000{ }^{\circ} \mathrm{C}$ to $1200{ }^{\circ} \mathrm{C}$ by Richardson, ${ }^{[34]}$ who determined these values by measurement of oxygen dissolved in $\mathrm{Pb}$ metal in equilibrium with slag. Sugimoto ${ }^{[35]}$ derived the activities of $\mathrm{PbO}$ from emf measurements undertaken at $1000{ }^{\circ} \mathrm{C}$. Ouchi ${ }^{[36]}$ used Knudsen mass-spectrometry to measure $\mathrm{PbO}$ vapor pressures relative to those in equilibrium with $\mathrm{PbSiO}_{3}$ at $1200{ }^{\circ} \mathrm{C}$.

Scheunis et al. ${ }^{[37,38]}$ studied the chemical corrosion of magnesia chromia refractories in the presence of synthetic $\mathrm{PbO}-\mathrm{MgO}-\mathrm{SiO}_{2}$ slags at $1200{ }^{\circ} \mathrm{C}$. It was found that the $\mathrm{MgO}$ phase in the refractories reacted with the slag to form olivine (forsterite, $\mathrm{Mg}_{2} \mathrm{SiO}_{4}$ ). It was shown that the formation of the secondary solid phases (olivine or pyroxene) can slow down the rate of dissolution but in excess they can destroy the refractory structure due to "forsterite bursting". ${ }^{[15]}$ The liquidus compositions of the $\mathrm{MgO}$-containing phases and limits of their primary phase fields are essential factors that determine the rates of dissolution of the refractory and the secondary phases formed.

The available experimental data do not cover the whole range of compositions encountered at the common industrial lead smelter operating conditions (1100 ${ }^{\circ} \mathrm{C}$ to $1200{ }^{\circ} \mathrm{C}$ ). This provides further motivation to undertake detailed experimental studies of phase equilibria in the $\mathrm{PbO}-\mathrm{MgO}-\mathrm{SiO}_{2}$ system, as the simplest key ternary that includes one refractory component $(\mathrm{MgO})$, one value metal oxide $(\mathrm{PbO})$ and one fluxing component $\left(\mathrm{SiO}_{2}\right)$ should be obtained.

The present study is also a part of a comprehensive integrated experimental and thermodynamic modeling research program focused on the thermodynamic characterization of the multi-component, multi-phase gasslag-matte-speiss-metal-solids system having $\mathrm{Pb}-\mathrm{Zn}-\mathrm{Cu}-\mathrm{Fe}-\mathrm{Si}-\mathrm{Ca}-\mathrm{O}-\mathrm{S}$ as the major elements present, Al- $\mathrm{Mg}-\mathrm{Cr}$ slagging or supplementary elements and $\mathrm{As}, \mathrm{Sn}, \mathrm{Sb}, \mathrm{Bi}, \mathrm{Ag}, \mathrm{Au}, \mathrm{Ni}$ and other minor elements distributed between the phases present in the system. ${ }^{[39,40]}$ The outcomes of this overall research program will include fundamental experimental measurements of phase equilibria and the development of a comprehensive, self-consistent thermodynamic database of the above system. During this integrated research, thermodynamic predictions are used to assist in planning of the experiments, and experimental results are in turn used to continuously improve the accuracy of this internal database. ${ }^{[41,42]}$ The database is used in conjunction with the FactSage computer package. ${ }^{[43,44]}$ The overall approach to the problem involves first identifying inconsistencies or uncertainties in the available data with the assistance of the existing database, selecting appropriate bulk compositions and process conditions to experimentally test the equilibria, comparing the new data with the current database predictions and then adjusting the database parameters to improve the description of the system. The process is repeated in different compositional areas within the system until the database has been optimized for the binary and ternary systems.

\section{EXPERIMENTAL METHODOLOGY}

Full details of the experimental technique and apparatus used in this study have been reported in previous publications by the authors. ${ }^{[45-47]}$ The initial chemical mixtures were prepared through blending of selected proportions of high-purity powders of $\mathrm{MgO}(99.95 \mathrm{wt}$ pct purity), $\mathrm{SiO}_{2}\left(99.9\right.$ wt pct purity, pre-dried at $400{ }^{\circ} \mathrm{C}$ for 1 hours before mixing) and $\mathrm{PbO}$ (99.9 wt pct purity) supplied by Alfa Aesar, USA. The $\mathrm{Pb}_{3} \mathrm{O}_{4}$ powder was prepared by oxidation of $\mathrm{PbO}$ powder in an $\mathrm{MgO}$ crucible in air for $24 \mathrm{~h}$ at $450{ }^{\circ} \mathrm{C}$. The formation of $\mathrm{Pb}_{3} \mathrm{O}_{4}$ was confirmed gravimetrically from the increase of weight ( $>99$ pct complete reaction) due to Reaction [1]. $\mathrm{PbO}$ and $\mathrm{Pb}_{3} \mathrm{O}_{4}$ are the only thermodynamically stable phases at the conditions of the synthesis, $450{ }^{\circ} \mathrm{C}$ and $1 \mathrm{~atm}$.

$$
3 \mathrm{PbO}+0.5 \mathrm{O}_{2}=\mathrm{Pb}_{3} \mathrm{O}_{4}
$$

To enable the approach to equilibrium to be tested from different starting compositions and to reduce the extent of lead oxide vaporization, a master slag of composition $\mathrm{Pb}_{4} \mathrm{Si}_{6} \mathrm{O}_{16}$ was prepared by mixing an appropriate ratio of $\mathrm{Pb}_{3} \mathrm{O}_{4}$ and dried $\mathrm{SiO}_{2}$ powders and heating initially for 2 hours at $600{ }^{\circ} \mathrm{C}$ and then for a further 2 hours at $900{ }^{\circ} \mathrm{C}$ in $\mathrm{Pt}$ crucible in air. Excess 


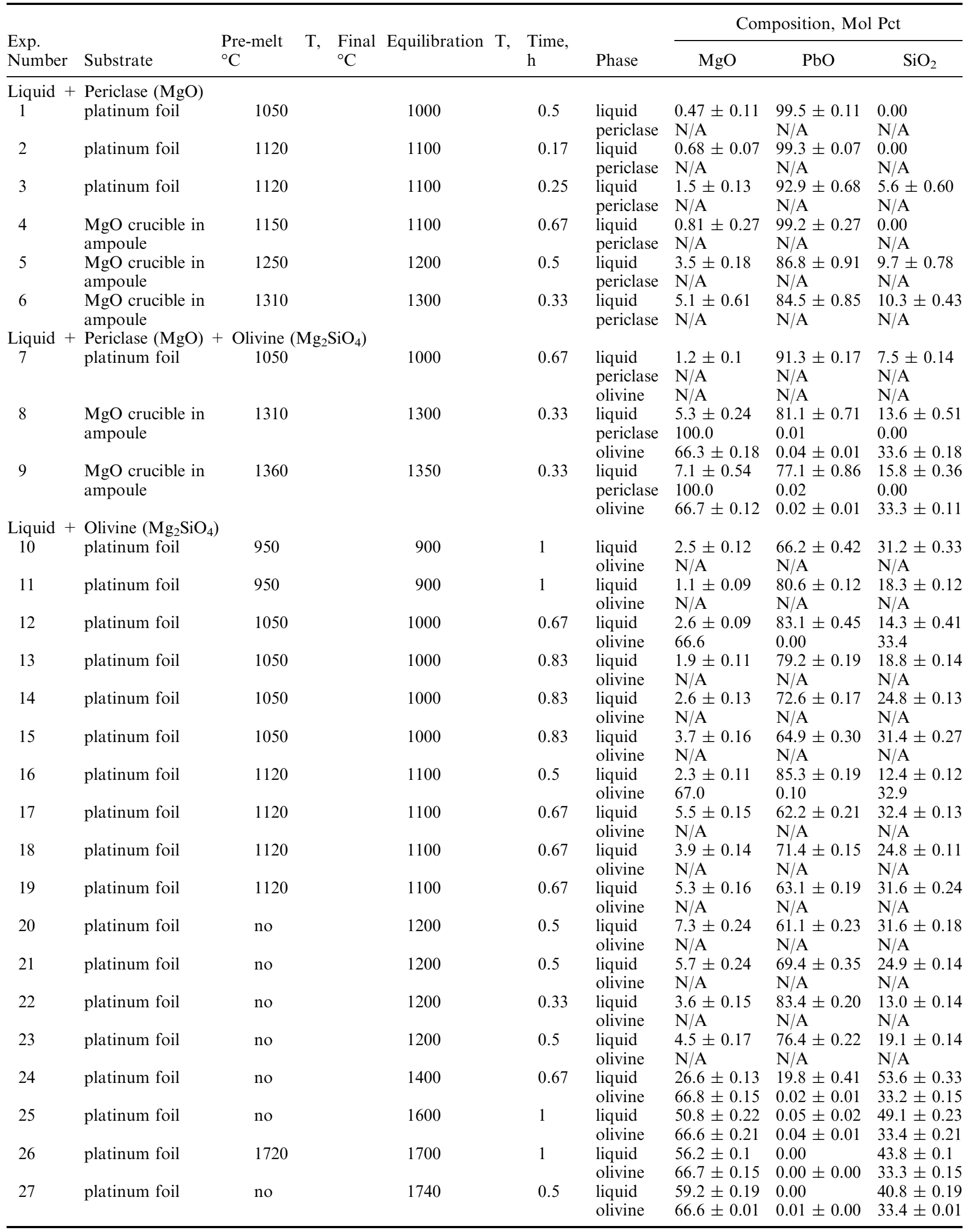




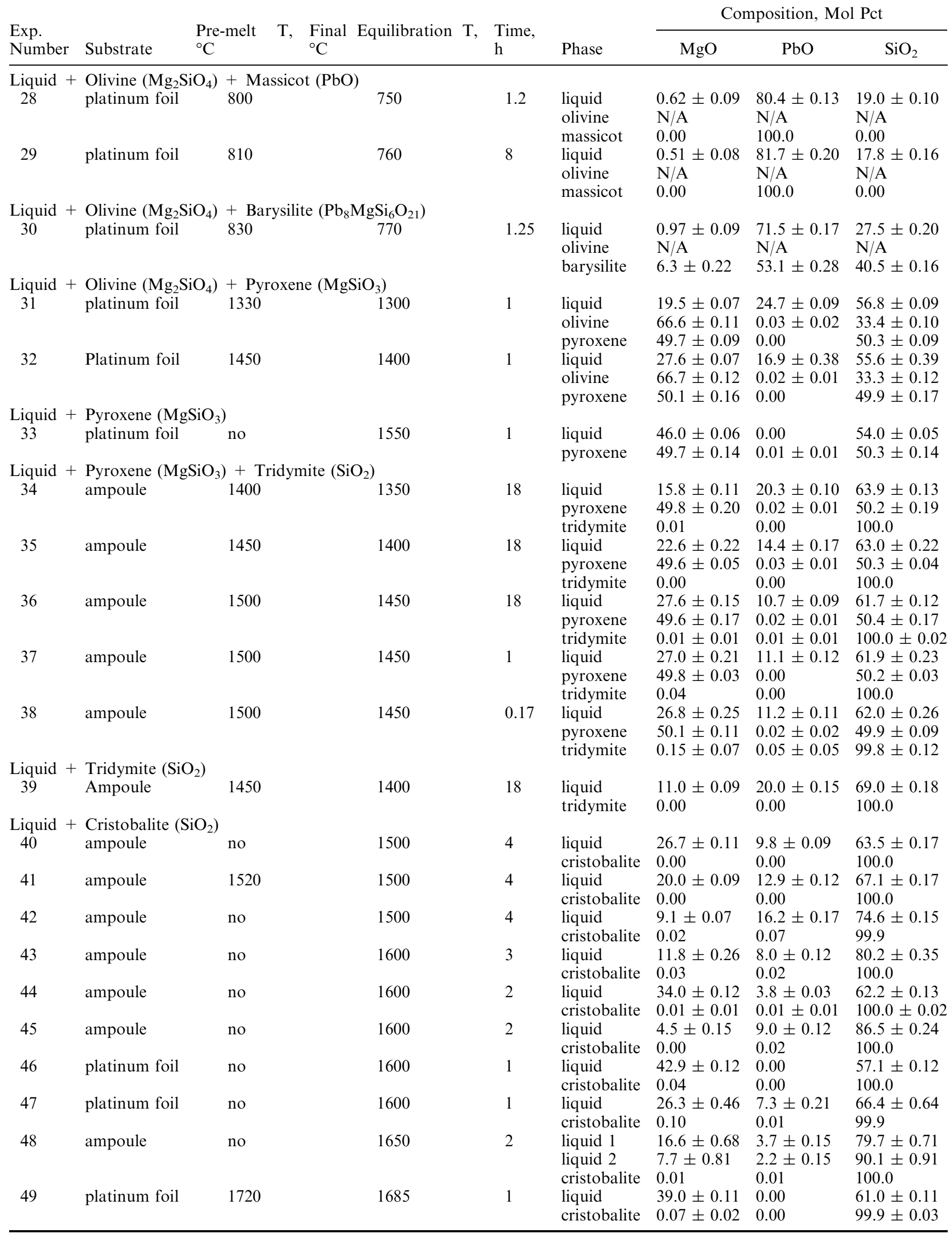


Table I. continued

\begin{tabular}{|c|c|c|c|c|c|c|c|c|}
\hline \multirow{2}{*}{$\begin{array}{l}\text { Exp. } \\
\text { Number }\end{array}$} & \multirow[b]{2}{*}{ Substrate } & \multirow[b]{2}{*}{ Pre-melt $\mathrm{T},{ }^{\circ} \mathrm{C}$} & \multirow[b]{2}{*}{ Final Equilibration $\mathrm{T},{ }^{\circ} \mathrm{C}$} & \multirow[b]{2}{*}{ Time, $\mathrm{h}$} & \multirow[b]{2}{*}{ Phase } & \multicolumn{3}{|c|}{ Composition, Mol Pct } \\
\hline & & & & & & $\mathrm{MgO}$ & $\mathrm{PbO}$ & $\mathrm{SiO}_{2}$ \\
\hline 50 & platinum foil & 1720 & 1700 & 1 & $\begin{array}{l}\text { liquid } \\
\text { cristobalite }\end{array}$ & $\begin{array}{l}38.1 \pm 0.14 \\
0.00\end{array}$ & $\begin{array}{l}0.00 \\
0.00\end{array}$ & $\begin{array}{l}61.9 \pm 0.14 \\
100.00\end{array}$ \\
\hline 51 & platinum foil & 1600 & 1550 & 2 & $\begin{array}{l}\text { liquid } \\
\text { cristobalite }\end{array}$ & $\begin{array}{l}44.3 \pm 0.13 \\
0.00\end{array}$ & $\begin{array}{l}0.00 \\
0.00\end{array}$ & $\begin{array}{l}55.7 \pm 0.13 \\
100.0\end{array}$ \\
\hline 52 & platinum foil & 1700 & 1650 & 1 & $\begin{array}{l}\text { liquid } \\
\text { cristobalite }\end{array}$ & $\begin{array}{l}40.9 \pm 0.16 \\
0.00\end{array}$ & $\begin{array}{l}0.00 \\
0.00\end{array}$ & $\begin{array}{l}59.1 \pm 0.16 \\
100.0\end{array}$ \\
\hline 2 Liquids & & & & & & & & \\
\hline 53 & platinum foil & 1725 & 1705 & 1 & $\begin{array}{l}\text { liquid } 1 \\
\text { liquid } 2\end{array}$ & $\begin{array}{l}37.7 \pm 0.13 \\
0.90 \pm 0.09\end{array}$ & $\begin{array}{l}0.00 \\
0.00\end{array}$ & $\begin{array}{l}62.3 \pm 0.13 \\
99.1 \pm 0.10\end{array}$ \\
\hline 54 & platinum foil & no & 1740 & 0.5 & $\begin{array}{l}\text { liquid } 1 \\
\text { liquid } 2\end{array}$ & $\begin{array}{l}36.7 \pm 0.11 \\
1.2 \pm 0.13\end{array}$ & $\begin{array}{l}0.00 \\
0.00\end{array}$ & $\begin{array}{l}63.3 \pm 0.11 \\
98.8 \pm 0.13\end{array}$ \\
\hline
\end{tabular}

$N / A$ data not available.

oxygen from $\mathrm{Pb}_{3} \mathrm{O}_{4}$ was released to atmosphere during heating, so that the final master slag contained only $\mathrm{Pb}^{2+[48]}$; direct use of $\mathrm{PbO}$ reagent was avoided to protect the Pt substrate from accidental destruction due to local reducing conditions, observed in some previous studies. ${ }^{[23]}$ The initial compositions of the mixtures were selected to ensure that, following equilibration, at least one crystalline phase would be present. To promote the retention of the liquid as an amorphous phase on quenching, the volume fraction of crystalline solid phase in the final sample was designed to be approximately 10 pct, but not more than 50 pct at the equilibration conditions. Pellets of $\sim 0.2$ to $0.3 \mathrm{~g}$ were made from the initial powder mixtures.

The substrates used for equilibration were (1) platinum foil envelopes, (2) vacuum sealed silica ampoules and (3) $\mathrm{MgO}$ crucibles in vacuum-sealed silica ampoules. The platinum foil crucibles were used for low-silica mixtures to achieve equilibrium with pyroxene (protoenstatite), olivine (forsterite), periclase, massicot and barysilite phases at the target experimental temperatures. The silica crucibles were used for high-silica mixtures that were in equilibrium with tridymite and cristobalite at the target temperature. The $\mathrm{MgO}$ crucibles in sealed silica ampoules (to prevent evaporation of $\mathrm{PbO}$ ) were used for high- $\mathrm{PbO}$ mixtures that were in equilibrium with periclase phase. There was no contact of the slag contained inside the $\mathrm{MgO}$ crucible with the outside silica ampoule. The open experiments were carried out in the air atmosphere.

The selection of the substrates was also to avoid any inclusion of the substrates into the equilibrated samples. The silica ampoule substrates would not contaminate the samples because of their high purity and coincidence with the primary phase (tridymite or cristobalite), the crystals of which would present in the sample. $\mathrm{MgO}$ crucibles contained a certain level of yttrium oxide. Yttrium was measured in slags in several selected samples, and no contamination was detected via EPMA $(<0.02 \mathrm{pct})$. Platinum foil could partially oxidize and dissolve in the slag as oxide (most likely PtO).
Concentrations of platinum in slag were tested through LA-ICPMS (laser ablation-inductively coupled plasma mass spectrometry), and they were found to vary between $<0.001$ wt pet for low-PbO slags $\left(\mathrm{MgO}-\mathrm{SiO}_{2}\right.$ system) and 0.02 to $0.07 \mathrm{wt}$ pet for high-PbO slags. In all cases, this contamination was below the scatter of EPMA measurements and was neglected.

The equilibration experiments were carried out in a high-temperature vertical tube resistance furnace. For experiments at $>1700{ }^{\circ} \mathrm{C}$, the melting temperature of cristobalite $\left(1723{ }^{\circ} \mathrm{C}\right)$ was used as an internal reference for thermocouple calibration. The sample was positioned in the uniform hot zone of the furnace suspended on a $\mathrm{Kanthal}(\mathrm{Fe}-\mathrm{Cr}-\mathrm{Al})$ wire, extended with $\mathrm{Pt}$ wire for the part that is required to heat above 1400 ${ }^{\circ} \mathrm{C}$. For the experiments at $<1600{ }^{\circ} \mathrm{C}$ the samples were first pre-melted at 20 to $50{ }^{\circ} \mathrm{C}$ above the experimental temperature for 5 minutes to ensure the formation of a homogeneous slag. Homogeneity of slags was tested by measuring compositional profiles through the sample on micro- and macro-scales. No inhomogeneity was observed on micro-scale. On macro-scale also, no compositional gradients were observed in the closed system samples but in the samples on platinum foil, occasionally minor areas depleted in $\mathrm{PbO}$ because of evaporation were found in the areas exposed to the surface; these areas were rejected when the average was calculated. Furthermore, previous studies of the authors $^{[23]}$ on the $\mathrm{PbO}-\mathrm{SiO}_{2}$ system did not encounter any phase separation. Moreover, in the present study, addition of $\mathrm{PbO}$ to the $\mathrm{MgO}-\mathrm{SiO}_{2}$ system where a relatively wide miscibility gap exists causes quick disappearance of immiscibility. Evaporation of $\mathrm{PbO}$ was the main challenge of the present study. The experimental time should be sufficient to achieve equilibrium in the sample; however, the activities and equilibrium vapor pressures of the lead-containing gas species vary with bulk composition of the sample. Shorter times are therefore used for experiments in which the predicted total vapor pressure of lead species is high. 
Following equilibration at the selected temperatures, the samples were quenched rapidly in calcium chloride-containing brine at $-20{ }^{\circ} \mathrm{C}$. After washing with water and ethanol, and drying, the specimen was mounted in epoxy resin and then polished to $1 \mu \mathrm{m}$ using conventional metallographic polishing techniques. The specimens were examined using optical microscopy and then carbon coated. The compositions of the phases present were measured using electron probe X-ray microanalysis (EPMA), JEOL 8200L EPMA; Japan Electron Optics Ltd., Tokyo, Japan. The EPMA was operated with a probe current of 20 $\mathrm{nA}$, accelerating voltage of $15 \mathrm{kV}$. The Duncumb-Philibert atomic number, absorption, and fluorescence correction (ZAF correction) were applied to the analyses obtained. Wollastonite $\left(\mathrm{CaSiO}_{3}\right)$ and magnesia (supplied by Charles M. Taylor Co., Stanford, $\mathrm{CA}$ ) and $\mathrm{PbO}-\mathrm{SiO}_{2} \mathrm{~K} 456$ glass (71.4 pet $\mathrm{PbO}$, supplied by NIST) were used for $\mathrm{Si}, \mathrm{Mg}$ and $\mathrm{Pb}$ calibration of the EPMA. Achievement of equilibrium in the samples was ensured by using the four-point test approach $^{[47,49]}$ : (1) variation of equilibration time, (2) assessment of the compositional homogeneity of phases by EPMA, (3) approaching the final equilibrium point from different starting conditions and (4) consideration of reactions specific to this system that may affect the achievement of equilibrium or reduce the accuracy. ${ }^{[47]}$ The ability to quench the liquid slag phase to ambient temperature without the onset of crystallization was found to depend on the composition of the slag and the equilibration temperature. Significant problems were observed with low-silica slags, where the glassy homogeneous areas were only a small proportion of the melt, believed to be formed at the surfaces directly contacting the quenching medium. For these samples the approach taken to obtain accurate, repeatable and objective measurements of the average compositions of the liquid slag phase by the use of EPMA was similar to that described by Nikolic et al. ${ }^{[50]}$ : an average of at least 20 points in the best quenched area (usually, near the surface) was used, additionally controlled by standard deviation of composition not exceeding 1 mol pct. In cases where melt crystallization was rapid, the experiments were repeated until an area of sufficiently wellquenched microstructure was found. Increasing the probe diameter to 20 to $50 \mu \mathrm{m}$ resulted in reduced variability of the measured liquid slag compositions. In addition, all samples were routinely tested for possible contaminations, and rejected in rare cases when they were detected. There were no signs of inhomogeneities related to poor mixing. Through the 20 to 30 points measured in 3 to 4 independent areas in each sample, the standard deviations were usually within 0.5 pct.

Calcium was measured in all samples to ensure that no reactions had taken place when quenching in the calcium chloride-containing brine. In most of the samples, the concentration of calcium was zero. In a few samples, some $\mathrm{CaCl}_{2}$ crystals were detected on the surfaces; however, calcium did not enter the bulk of the slag.

\section{THERMODYNAMIC MODELING}

The FactSage 7.2 thermodynamic package ${ }^{[43]}$ and an internal thermodynamic database were used for modeling in the present study. Thermodynamic parameters of tridymite and cristobalite $\left(\mathrm{SiO}_{2}\right)$, periclase $(\mathrm{MgO})$, olivine (forsterite $\mathrm{Mg}_{2} \mathrm{SiO}_{4}$ ), pyroxene (protoenstatite $\mathrm{MgSiO}_{3}$ ), massicot (PbO), lead silicates $\left(\mathrm{PbSiO}_{3}, \mathrm{~Pb}_{2} \mathrm{SiO}_{4}\right.$, $\left.\mathrm{Pb}_{11} \mathrm{Si}_{3} \mathrm{O}_{17}, \mathrm{~Pb}_{5} \mathrm{SiO}_{7}\right)$ and the parameters of the binary $\mathrm{MgO}-\mathrm{SiO}_{2}$ and $\mathrm{PbO}-\mathrm{SiO}_{2}$ liquids were taken from the previous studies. ${ }^{[30,51,52]}$ The binary parameters $\mathrm{PbO}-\mathrm{MgO}$ and ternary $\mathrm{PbO}-\mathrm{MgO}-\mathrm{SiO}_{2}$ and the properties of the only stable ternary compound, barysilite $\mathrm{Pb}_{8} \mathrm{MgSi}_{6} \mathrm{O}_{21}$, were identified and optimized as part of the present study. The slag phase is described using a modified quasichemical (GUTS formalism, i.e., with expansion of the excess Gibbs energy parameters in terms of pair fractions ${ }^{[53-56]}$, which combines Gibbs energy parameters of three types: (1) the Bragg-Williams model, a polynomial in terms of pure component concentrations to describe the random mixing configuration of entropy; (2) the quasichemical model, assuming the formation of $\mathrm{A}-\mathrm{A}$, $\mathrm{B}-\mathrm{B}$ and $\mathrm{A}-\mathrm{B}$ pairs with Gibbs free energies that are polynomial functions of the overall composition; (3) the GUTS model, assuming the formation of pairs with Gibbs free energies that are polynomial functions of pair fractions. The binary parameters are projected toward ternary and multicomponent systems using the geometric formalism developed by Pelton et al. ${ }^{[57,58]}$ with the Toop (asymmetrical) approach: the acidic component $\mathrm{SiO}_{2}$ is placed at the top of the Toop model triangle, while the basic $\mathrm{PbO}$ and $\mathrm{MgO}$ are placed at its base.

\section{RESULTS AND DISCUSSION}

Figure 1 shows micrographs of the quenched $\mathrm{PbO}-\mathrm{MgO}-\mathrm{SiO}_{2}$ samples at selected temperatures and bulk compositions illustrating the phase assemblages observed on equilibration. Examples of microstructures are presented for massicot-olivine equilibrium at $760{ }^{\circ} \mathrm{C}$ in Figure 1(a), pericase-olivine at $1350^{\circ} \mathrm{C}$ in Figure 1(b), two liquids in equilibrium with cristobalite at $1650{ }^{\circ} \mathrm{C}$ in Figure 1(d), olivine-pyroxene at $1400^{\circ} \mathrm{C}$ in Figure 1(f), tridymite-pyroxene at $1450{ }^{\circ} \mathrm{C}$ in Figure $1(\mathrm{~g})$ and olivine-barysilite at $770{ }^{\circ} \mathrm{C}$ in Figure $1(\mathrm{~h})$.

The experimental results for the ternary $\mathrm{PbO}-\mathrm{MgO}-$ $\mathrm{SiO}_{2}$ liquidus are given in Table I and shown in Figures 2 and 3. The exact compositions of some of the solid phases listed in Table I are marked as "not available" $(\mathrm{N} / \mathrm{A})$. The very small size of the crystals, in these cases, meant that accurate quantitative measurements of the compositions of the solid phases could not be undertaken; for example, see Figure 1(a) for the olivine phase. These solid phases were, however, qualitatively identified through energy-dispersive spectroscopy (EDS).

The effect of reaction/experimental time on the equilibrium was studied through three experiments using one selected slag composition to determine the tridymite-pyroxene boundary phase at $1450{ }^{\circ} \mathrm{C}$; see the 


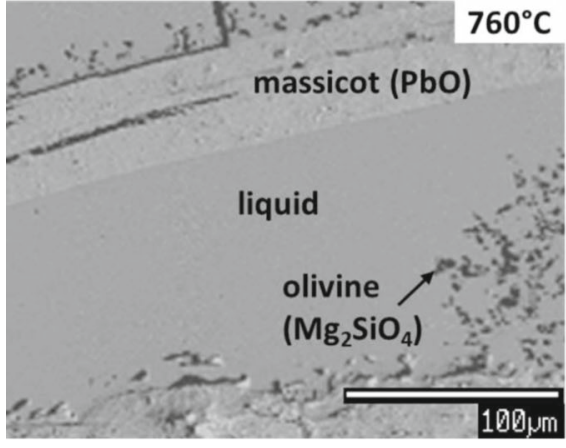

(a) liquid (26) + olivine (forsterite) + massicot

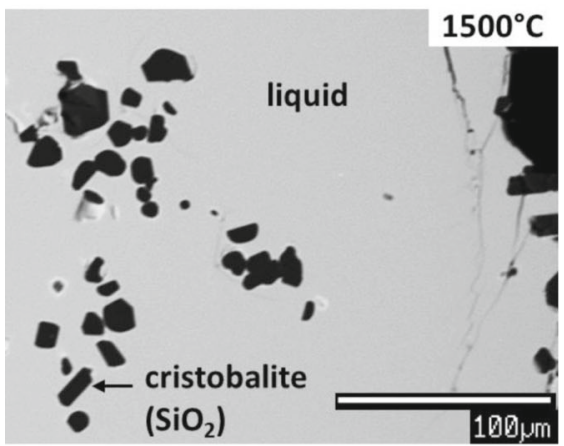

(c) liquid (42) + cristobalite

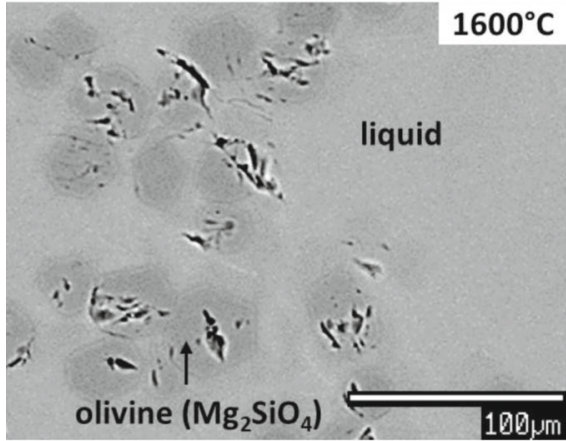

(e) liquid (25) + olivine (forsterite)

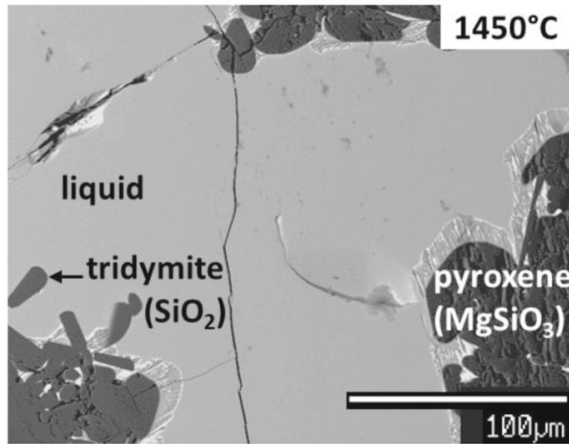

(g) liquid (36) + pyroxene (protoenstatite) + tridymite

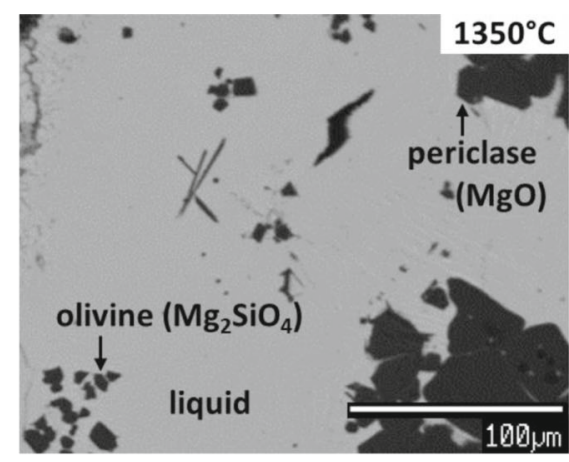

(b) liquid (9) + olivine (forsterite) + periclase

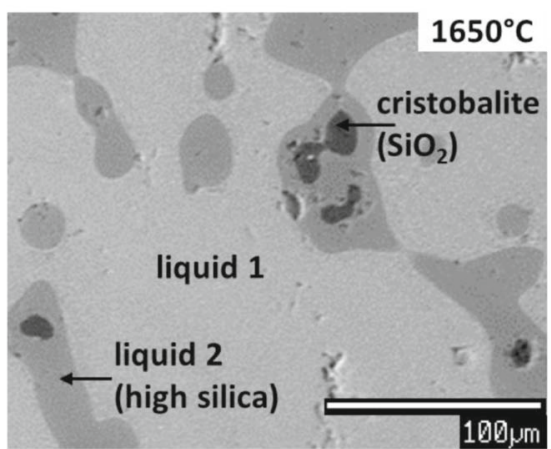

(d) liquid $1(48)+$ liquid $2(48)+$ cristobalite

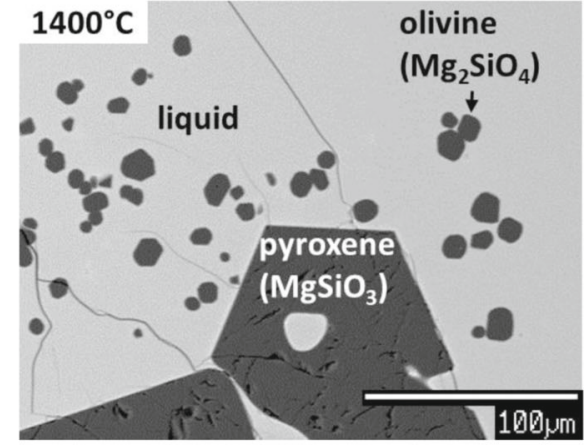

(f) liquid (32) + olivine (forsterite) + pyroxene (protoenstatite)

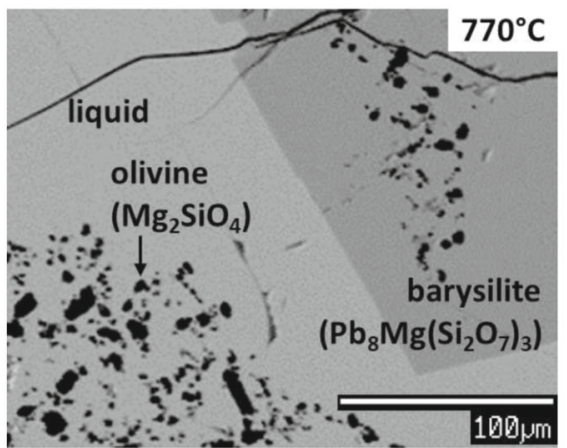

(h) liquid (30) + olivine (forsterite) + barysilite

Fig. 1-Back-scattered electron micrographs of typical phase assemblages in the $\mathrm{PbO}-\mathrm{MgO}-\mathrm{SiO}_{2}$ system, illustrating the presence of $(a)$ liquid slag, olivine (fosterite) and massicot at $760{ }^{\circ} \mathrm{C},(b)$ liquid slag, olivine (fosterite) and periclase at $1000{ }^{\circ} \mathrm{C},(c)$ liquid slag and cristobalite at $1500{ }^{\circ} \mathrm{C},(d)$ two-liquid immiscibility formation and cristobalite at $1650{ }^{\circ} \mathrm{C},(e)$ liquid slag and olivine (fosterite) at $1600{ }^{\circ} \mathrm{C}$, $(f)$ liquid slag, olivine (fosterite) and pyroxene (protoenstatite) at $1450{ }^{\circ} \mathrm{C},(g)$ liquid slag, pyroxene (protoenstatite) and tridymite at $1450{ }^{\circ} \mathrm{C}$ and $(h)$ liquid slag, olivine (fosterite) and barysilite at $770{ }^{\circ} \mathrm{C}$. The numbers in brackets for each liquid slag represent the experiment number as given in Table I. 


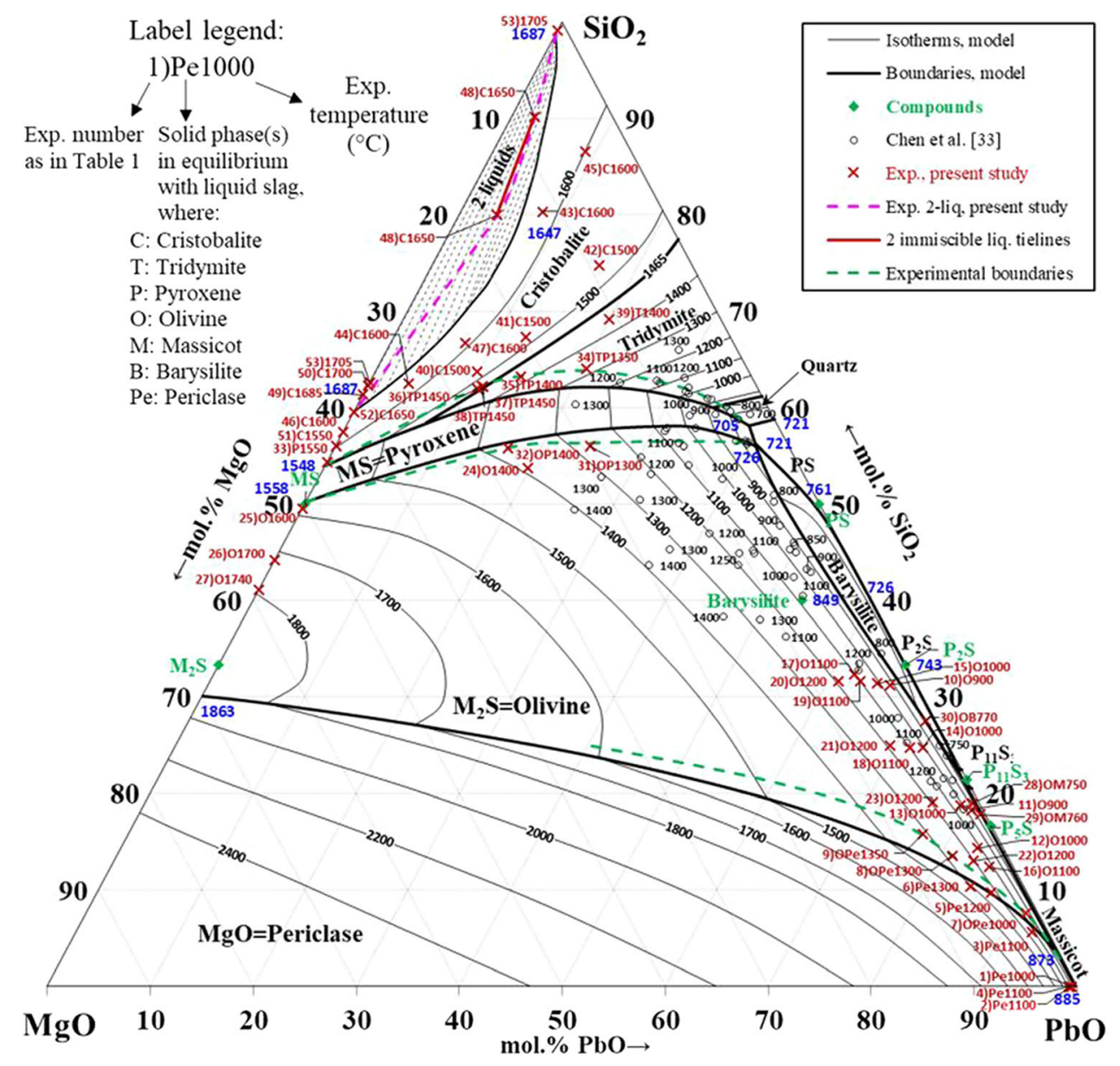

Fig. 2- Liquidus surfaces of the $\mathrm{PbO}-\mathrm{MgO}-\mathrm{SiO}_{2}$ system according to the new experimental results at $750{ }^{\circ} \mathrm{C}$ to $1740{ }^{\circ} \mathrm{C}$ and estimated with the currently optimized thermodynamic database. Legend for the experimental points: $\times$ current study; $\bigcirc$ from Ref. [33].

composition of the liquid slags for experiments 36 to 38 , given in Table I. The slag compositions are the same within the range of uncertainty of the EPMA measurements, and the liquid is in equilibrium with tridymite and pyroxene for reaction times of $0.17,1$ and 18 hours.

Note that the full lines denoting the phase boundaries and liquidus isotherms included in Figures 2 and 3 are not drawn using the existing FactSage public slag database but using the thermodynamic parameters of the slag and solid phases obtained after optimizing the available experimental data from the binary systems and from the present study. This reflects the integrated approach taken to selection of compositions to be investigated experimentally. By undertaking the thermodynamic optimization of the available experimental data, the information is tested for internal thermodynamic consistency, i.e., the description obeys the laws of thermodynamics, and to avoid relying on data that may be misleading or have high variance. The proximity of the experimental data and the predicted behavior is therefore confirmation of the accuracy of the current internal database. The optimized thermodynamic parameters of the slag and solid phases are listed in Table II. The $\mathrm{PbO}-\mathrm{MgO}-\mathrm{SiO}_{2}$ ternary system has 11 primary phase fields, cristobalite and tridymite $\left(\mathrm{SiO}_{2}\right)$, periclase $(\mathrm{MgO})$, olivine (forsterite, $\mathrm{Mg}_{2} \mathrm{SiO}_{4}$ ), pyroxene (protoenstatite, $\mathrm{MgSiO}_{3}$ ), massicot $(\mathrm{PbO})$, lead silicates $\left(\mathrm{PbSiO}_{3}\right.$ or $\mathrm{PS} ; \mathrm{Pb}_{2} \mathrm{SiO}_{4}$ or $\mathrm{P}_{2} \mathrm{~S} ; \mathrm{Pb}_{11} \mathrm{Si}_{3} \mathrm{O}_{17}$ or $\mathrm{P}_{11} \mathrm{~S}_{3}$; $\mathrm{Pb}_{5} \mathrm{SiO}_{7}$ or $\mathrm{P}_{5} \mathrm{~S}$, ) and barysilite $\left(\mathrm{Pb}_{8} \mathrm{MgSi}_{6} \mathrm{O}_{21}\right.$ or $\mathrm{P}_{8} \mathrm{MS}_{6}$ ). Barysilite is a generic name for all $\mathrm{Pb}_{8} \mathrm{XSi}_{6} \mathrm{O}_{21}$ structures, where $\mathrm{X}$ may be $\mathrm{Pb}^{2+}, \mathrm{Mn}^{2+}, \mathrm{Fe}^{2+}, \mathrm{Mg}^{2+}$, $\mathrm{Zn}^{2+}, \mathrm{Ca}^{2+}, \mathrm{Cu}^{2+}$, etc. ${ }^{[59-62]}$ These appear to form limited solid solutions between the end members, The $\mathrm{Pb}$ end member $\left(\mathrm{Pb}_{9} \mathrm{Si}_{6} \mathrm{O}_{21}=3 \mathrm{~Pb}_{3} \mathrm{Si}_{2} \mathrm{O}_{7}\right)$ does not reach the liquidus. ${ }^{[23]}$ No solid solution from $\mathrm{Pb}_{8} \mathrm{MgSi}_{6} \mathrm{O}_{21}$ toward $\mathrm{Pb}_{9} \mathrm{Si}_{6} \mathrm{O}_{21}$ was detected in the present study. That may be a consequence of the large difference between $\mathrm{Mg}^{2+}$ and $\mathrm{Pb}^{2+}$ ionic radii, which results in immiscibility between these two end members. The entropies and heat capacities of $\mathrm{Pb}_{8} \mathrm{MgSi}_{6} \mathrm{O}_{21}$ were obtained from simple linear combination of the close compounds- $-\mathrm{MgO}+4 \mathrm{PbSiO}_{3}+2 \mathrm{~Pb}_{2} \mathrm{SiO}_{4}$. The enthalpy of formation was found by fitting the liquidus experimental data. According to Reference 33 and the present study, the $\mathrm{Pb}_{2} \mathrm{MgSi}_{2} \mathrm{O}_{7}$ melilite end member is unstable.

The phase equilibria data reported on the $\mathrm{PbO}-\mathrm{SiO}_{2}$ binary were taken from research by $\mathrm{Jak}$ et al. ${ }^{[22]}$ and Shevchenko and Jak. ${ }^{[23]}$ The data for the $\mathrm{MgO}-\mathrm{SiO}_{2}$ binary have been obtained from experimental studies by 


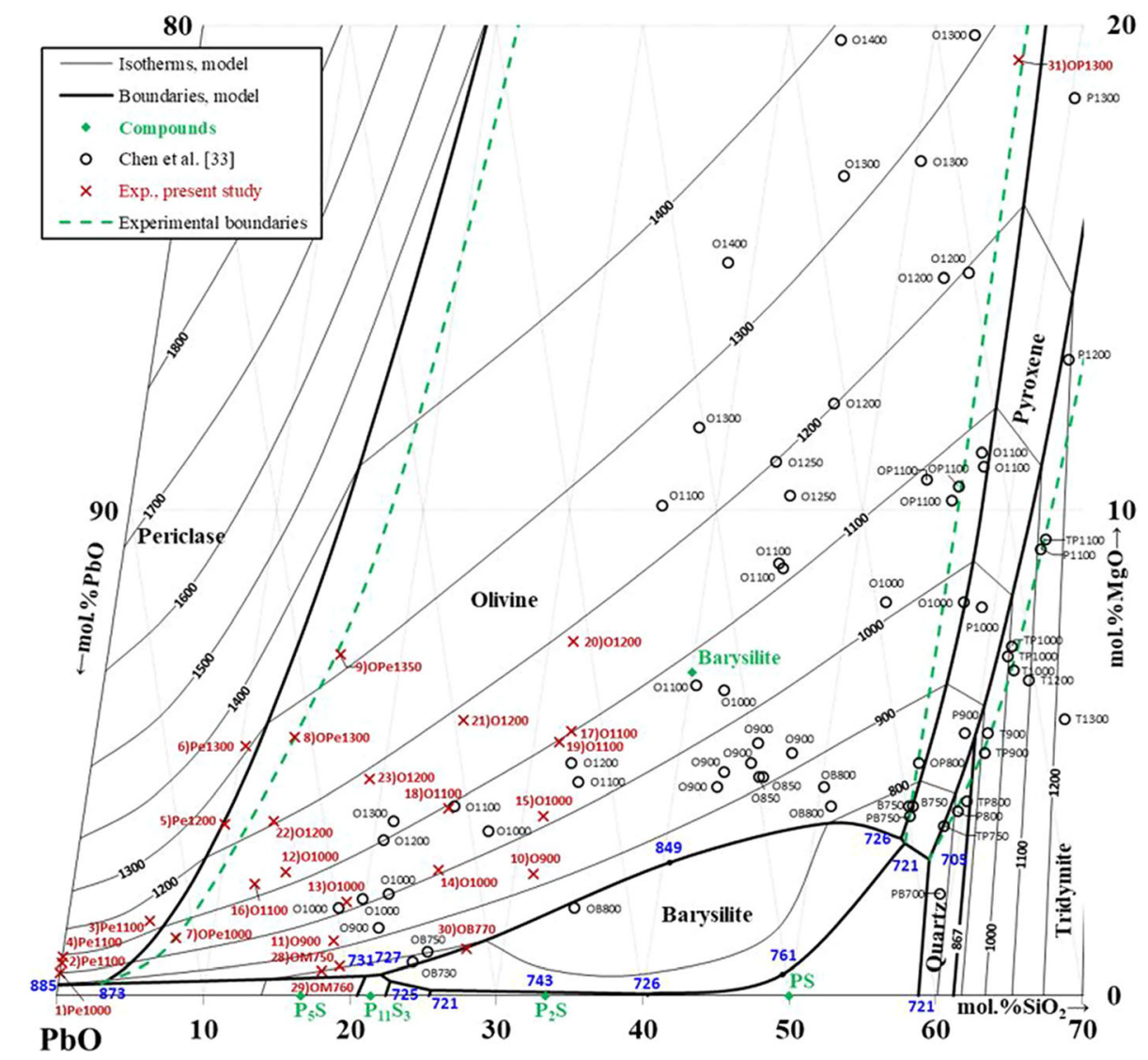

Fig. 3-Details of the high- $\mathrm{PbO}$ region of the liquidus surface of the $\mathrm{PbO}-\mathrm{MgO}-\mathrm{SiO}_{2}$ system according to the new experimental results at 750 ${ }^{\circ} \mathrm{C}$ to $1740{ }^{\circ} \mathrm{C}$. The phase boundaries and liquidus isotherms are estimated using the currently optimized thermodynamic database. Legend for the experimental points: $\times$ current study; $\bigcirc$ from Ref. [33].

Table II. Thermodynamic Parameters of the PbO-MgO-SiO ${ }_{2}$ System Optimised in the Present Study (J/mol)

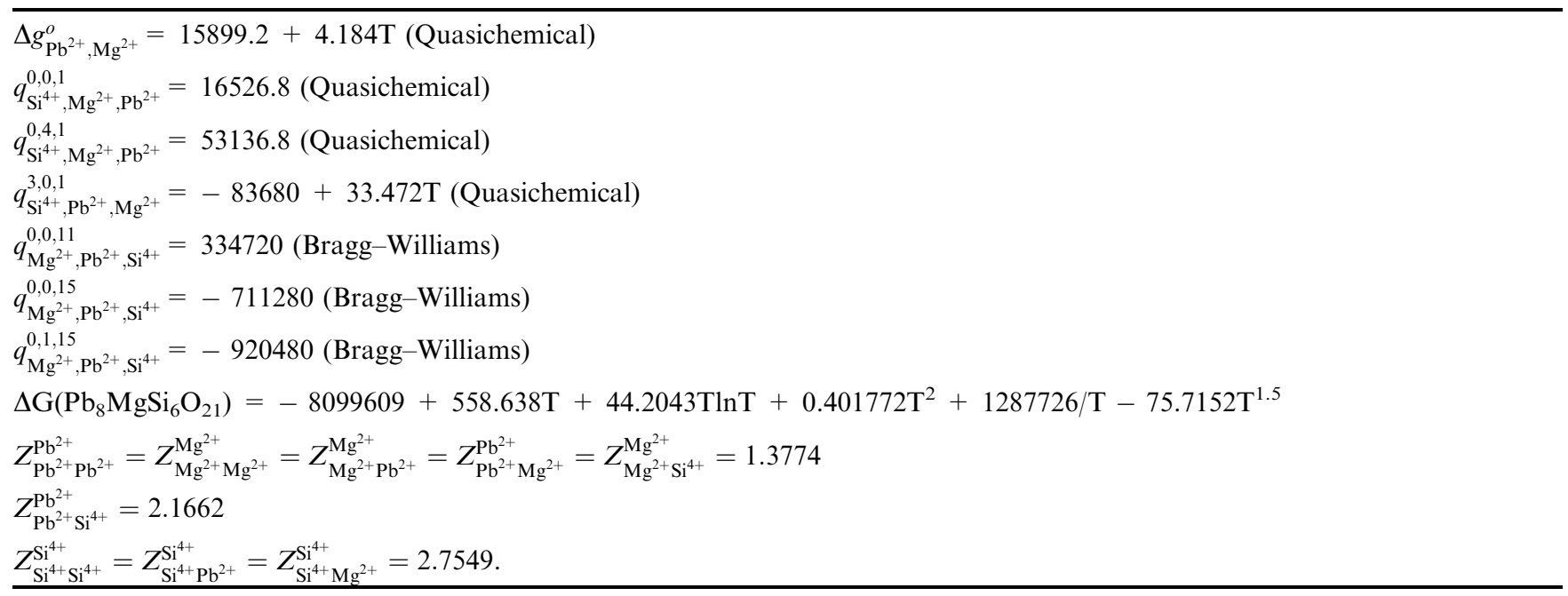

Greig, ${ }^{[25,63]}$ Bowen and Anderson, ${ }^{[26]}$ Schlaudt and $\operatorname{Roy}^{[27]}$ and thermodynamic modeling by $\mathrm{Wu}$ et al. ${ }^{[30]}$ The experimental results given in Table I and shown in Figure 2 indicate that the two-liquid immiscibility on the $\mathrm{MgO}-\mathrm{SiO}_{2}$ binary in the high-silica region extends into the ternary system. The sample obtained at $1650{ }^{\circ} \mathrm{C}$ shows the two-liquid immiscibility in the presence of the cristobalite phase (see Figure 1(d)). Based on these results, the new proposed boundary line between cristobalite primary phase field and the two-liquid 
immiscibility region is shown with the pink dashed line in Figure 2, that is, a slightly smaller composition region than predicted with the current thermodynamic database. New experimental results demonstrated that liquid immiscibility in the high-silica region of the $\mathrm{PbO}$ $\mathrm{MgO}-\mathrm{SiO}_{2}$ ternary shrinks significantly from $\sim 40$ to $\sim 10$ pet as 3 pct $\mathrm{PbO}$ is added to the $\mathrm{MgO}-\mathrm{SiO}_{2}$ binary and temperature is lowered from $1700{ }^{\circ} \mathrm{C}$ to $1650{ }^{\circ} \mathrm{C}$. From that it can be extrapolated that the miscibility gap will close at further small addition of $\mathrm{PbO}$ and no more immiscible ranges would exist in this ternary system below $\sim 1640{ }^{\circ} \mathrm{C}$. In addition, in the cristobalite primary phase field, the $1500{ }^{\circ} \mathrm{C}$ and $1600{ }^{\circ} \mathrm{C}$ liquidus isotherms, and in the tridymite primary phase field the $1400{ }^{\circ} \mathrm{C}$ liquidus isotherm, were determined for compositions between the $\mathrm{MgO}-\mathrm{SiO}_{2}$ binary and $\mathrm{PbO}-\mathrm{SiO}_{2}$ binary.

Furthermore, Figure 2 indicates that the pyroxene primary phase field is slightly expanded toward both the tridymite and olivine primary phase fields relative to that currently described by the database. EPMA measurements for experiments at $1400{ }^{\circ} \mathrm{C}$ and $1450{ }^{\circ} \mathrm{C}$ showed the silica concentrations in slag in both equilibrium tridymite and pyroxene phases (Figure $1(\mathrm{~g})$ ) to be higher than predicted by the current database. Also, composition of the sample at $1400{ }^{\circ} \mathrm{C}$ indicates the liquid in equilibrium with pyroxene and olivine (Figure 1(f)) contains slightly less silica than predicted in the current model. The green dashed lines in Figure 2 indicate the proposed tridymite-pyroxene and pyroxene-olivine phase boundaries.

In the olivine primary phase field, the results obtained for experiments in the range of $750{ }^{\circ} \mathrm{C}$ to $1200^{\circ} \mathrm{C}$ show that the liquidus isotherms are at slightly higher $\mathrm{MgO}$ concentrations than reported by Chen et al. ${ }^{[33]}$ The periclase-olivine phase boundary appears to be at slightly higher (approximately $2 \mathrm{~mol}$ pct) silica concentrations than predicted by the database.

The phase diagram of the $\mathrm{MgO}-\mathrm{SiO}_{2}$ system according to the new experimental results at $1550{ }^{\circ} \mathrm{C}$ to 1740 ${ }^{\circ} \mathrm{C}$ compared to the present thermodynamic database (all parameters adopted from $\mathrm{Wu}$ et al. ${ }^{[30]}$ ) is given in Figure 4. Both cristobalite liquidus at $1550{ }^{\circ} \mathrm{C}$ to 1700 ${ }^{\circ} \mathrm{C}$ and olivine liquidus at $1700{ }^{\circ} \mathrm{C}$ to $1740{ }^{\circ} \mathrm{C}$ were found to be lower than predicted by the database.

The monotectic point in the $\mathrm{MgO}-\mathrm{SiO}_{2}$ system was found experimentally in the present study between 1700 ${ }^{\circ} \mathrm{C}$ and $1705^{\circ} \mathrm{C}$; the compositions of two liquids at the monotectic temperature are $62.1 \pm 0.2$ and $99.1 \pm 0.2$ mol pct $\mathrm{SiO}_{2}$. These values agree with those reported by Greig $^{[25]}$ but are higher than predicted by the present thermodynamic database, and the composition of the lower- $\mathrm{SiO}_{2}$ liquid is 1.5 to $2 \mathrm{~mol}$ pet higher in $\mathrm{SiO}_{2}$ than predicted.

The melting temperature of stoichiometric olivine $\left(\mathrm{Mg}_{2} \mathrm{SiO}_{4}\right)$ in the present study has been assumed to be $1888{ }^{\circ} \mathrm{C}$, the value reported by Bowen. ${ }^{[26]}$ However, Richet et al. ${ }^{[64]}$ report a value of $1826{ }^{\circ} \mathrm{C}$ and $\mathrm{Jung}^{[65]}$ reports values of $1855{ }^{\circ} \mathrm{C}$ to $1860{ }^{\circ} \mathrm{C}$. This range of temperatures is out of the scope of the present study, and confirmation of the melting point of olivine, the olivine/ periclase eutectic temperature and the olivine liquidus compositions at these high temperatures is recommended to enable the thermodynamic model parameters in the database to be unambiguously determined.

The compositions and the temperatures of the invariant reactions can be determined directly using the present technique; however, in most cases, they are evaluated from analysis of the multiple experimental

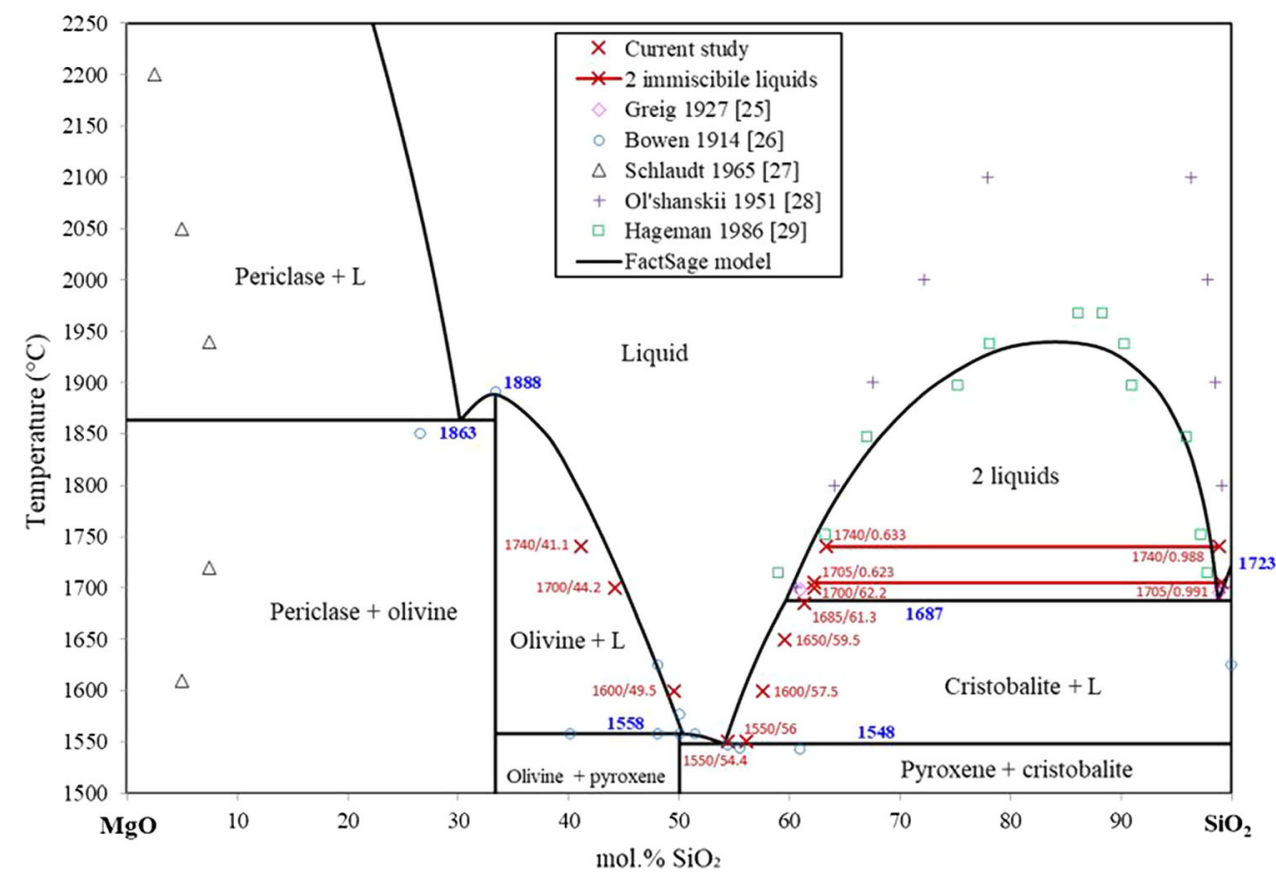

Fig. 4 - Phase diagram of the $\mathrm{MgO}-\mathrm{SiO}_{2}$ system according to the new experimental results at 1550 to $1740{ }^{\circ} \mathrm{C}$, literature data ${ }^{[25-29]}$ and estimated with the current thermodynamic database adopted from Wu et al. ${ }^{[30]}$. The labels indicate the experimental temperature and $\mathrm{SiO}_{2} \mathrm{~mole}^{\circ}$ fraction. 


\begin{tabular}{|c|c|c|c|c|}
\hline \multirow[b]{2}{*}{ Reaction } & \multirow[b]{2}{*}{$\mathrm{T}_{\text {model }},{ }^{\circ} \mathrm{C}$} & \multicolumn{3}{|c|}{ Mol Pct, Liquid } \\
\hline & & $\mathrm{PbO}$ & $\mathrm{MgO}$ & $\mathrm{SiO}_{2}$ \\
\hline $\mathrm{L}=\mathrm{MgSiO}_{3}$ (Protopyroxene) $+\mathrm{SiO}_{2}$ (Cristobalite) & 1548 & 0 & 45.9 & 54.1 \\
\hline $\mathrm{L}+\mathrm{Mg}_{2} \mathrm{SiO}_{4}$ (Olivine) $=\mathrm{MgSiO}_{3}$ (Protopyroxene) & 1558 & 0 & 49.7 & 50.3 \\
\hline $\mathrm{L}=\mathrm{MgO}$ (Periclase) $+\mathrm{Mg}_{2} \mathrm{SiO}_{4}$ (Olivine) & 1863 & 0 & 69.9 & 30.1 \\
\hline \multirow[t]{2}{*}{ Monotectic: $\mathrm{L} 2=\mathrm{L} 1+\mathrm{SiO}_{2}$ (Cristobalite) } & 1687 & 0 & 40.4 & 59.6 \\
\hline & & 0 & 1.24 & 98.76 \\
\hline $\mathrm{L}=\mathrm{MgO}$ (Periclase) $+\mathrm{PbO}$ (Massicot) & 885 & 99.78 & 0.22 & 0 \\
\hline $\mathrm{L}+\mathrm{PbO}($ Massicot $)=\mathrm{Pb}_{5} \mathrm{SiO}_{7}$ & 733 & 79.5 & 0 & 20.5 \\
\hline $\mathrm{L}+\mathrm{Pb}_{5} \mathrm{SiO}_{7}=\mathrm{Pb}_{11} \mathrm{Si}_{3} \mathrm{O}_{17}$ & 726 & 77.6 & 0 & 22.4 \\
\hline $\mathrm{L}=\mathrm{Pb}_{11} \mathrm{Si}_{3} \mathrm{O}_{17}+\mathrm{Pb}_{2} \mathrm{SiO}_{4}$ & 721 & 74.6 & 0 & 25.4 \\
\hline $\mathrm{L}=\mathrm{Pb}_{2} \mathrm{SiO}_{4}+\mathrm{PbSiO}_{3}$ & 726 & 59.7 & 0 & 40.3 \\
\hline $\mathrm{L}=\mathrm{PbSiO}_{3}+\mathrm{SiO}_{2}($ Quartz $)$ & 721 & 41.2 & 0 & 58.8 \\
\hline $\mathrm{L}+\mathrm{MgO}($ Periclase $)=\mathrm{PbO}($ Massicot $)+\mathrm{Mg}_{2} \mathrm{SiO}_{4}$ (Olivine $)$ & 873 & 96.8 & 0.25 & 2.9 \\
\hline $\mathrm{L}+\mathrm{PbO}($ Massicot $)=\mathrm{Pb}_{5} \mathrm{SiO}_{7}+\mathrm{Mg}_{2} \mathrm{SiO}_{4}$ (Olivine) & 731 & 78.8 & 0.40 & 20.9 \\
\hline $\mathrm{L}+\mathrm{Mg}_{2} \mathrm{SiO}_{4}$ (olivine) $=\mathrm{Pb}_{5} \mathrm{SiO}_{7}+\mathrm{Pb}_{8} \mathrm{MgSi}_{6} \mathrm{O}_{21}$ (Barysilite) & 727 & 77.7 & 0.42 & 21.9 \\
\hline $\mathrm{L}+\mathrm{Pb}_{5} \mathrm{SiO}_{7}=\mathrm{Pb}_{11} \mathrm{Si}_{3} \mathrm{O}_{17}+\mathrm{Pb}_{8} \mathrm{MgSi}_{6} \mathrm{O}_{21}$ (Barysilite) & 725 & 77.1 & 0.29 & 22.6 \\
\hline $\mathrm{L}=\mathrm{Pb}_{11} \mathrm{Si}_{3} \mathrm{O}_{17}+\mathrm{Pb}_{2} \mathrm{SiO}_{4}+\mathrm{Pb}_{8} \mathrm{MgSi}_{6} \mathrm{O}_{21}$ (Barysilite) & 721 & 74.4 & 0.11 & 25.5 \\
\hline $\mathrm{L}=\mathrm{Pb}_{2} \mathrm{SiO}_{4}+\mathrm{PbSiO}_{3}+\mathrm{Pb}_{8} \mathrm{MgSi}_{6} \mathrm{O}_{21}$ (Barysilite) & 726 & 59.6 & 0.03 & 40.3 \\
\hline $\mathrm{L}+\mathrm{Mg}_{2} \mathrm{SiO}_{4}$ (Olivine) $=\mathrm{MgSiO}_{3}$ (Protopyroxene) $+\mathrm{Pb}_{8} \mathrm{MgSi}_{6} \mathrm{O}_{21}$ (Barysilite) & 731 & 41.4 & 2.5 & 56.1 \\
\hline $\mathrm{L}+\mathrm{Pb}_{8} \mathrm{MgSi}_{6} \mathrm{O}_{21}$ (Barysilite) $=\mathrm{MgSiO}_{3}$ (Protopyroxene) $+\mathrm{PbSiO}_{3}$ & 725 & 41.2 & 2.4 & 56.4 \\
\hline $\mathrm{L}=\mathrm{MgSiO}_{3}$ (Protopyroxene) $+\mathrm{PbSiO}_{3}+\mathrm{SiO}_{2}$ (Quartz) & 709 & 39.6 & 2.1 & 58.3 \\
\hline Saddle: $\mathrm{L}+\mathrm{Mg}_{2} \mathrm{SiO}_{4}$ (Olivine) $=\mathrm{Pb}_{8} \mathrm{MgSi}_{6} \mathrm{O}_{21}$ (Barysilite) & 851 & 57.1 & 2.4 & 40.5 \\
\hline Saddle: $\mathrm{L}=\mathrm{Pb}_{8} \mathrm{MgSi}_{6} \mathrm{O}_{21}$ (Barysilite) $+\mathrm{Pb}_{2} \mathrm{SiO}_{4}$ & 743 & 66.5 & 0.07 & 33.4 \\
\hline Saddle: $\mathrm{L}=\mathrm{Pb}_{8} \mathrm{MgSi}_{6} \mathrm{O}_{21}$ (Barysilite) $+\mathrm{PbSiO}_{3}$ & 762 & 50.2 & 0.36 & 49.5 \\
\hline
\end{tabular}

points at constant temperatures. The invariant reactions calculated with FactSage using the database developed in the present study are given in Table III.

The activities of $\mathrm{PbO}$ at $1000{ }^{\circ} \mathrm{C}$ and $1200{ }^{\circ} \mathrm{C}$ relative to pure liquid $\mathrm{PbO}$ in the areas of liquid, liquid + one solid and liquid +2 solids are compared to the data reported by Richardson ${ }^{[34]}$ and Sugimoto ${ }^{[35]}$; see Figures 5(a) and (b). The data by Ouchi ${ }^{[36]}$ were not used because they were not presented relative to pure $\mathrm{PbO}$. There is a reasonable agreement between the literature data and the present study calculation, although the presence of solids (olivine) was not considered in the literature studies. The addition of $\mathrm{MgO}$ to the $\mathrm{PbO}-\mathrm{SiO}_{2}$ slags causes a slight increase in $\mathrm{a}(\mathrm{PbO})$ according to both our calculation and the literature data. The activities of $\mathrm{PbO}$ calculated in the present study in the vicinity of 50 pct $\mathrm{PbO}-50$ pct $\mathrm{SiO}_{2}$ composition are higher than reported in References 34, 35; however, they are within the limits of discrepancy of other literature data for the $\mathrm{PbO}-\mathrm{SiO}_{2}$ system, as reviewed in the previous study by the authors. ${ }^{[52]}$

\section{A. Application to Interpretation of Slag-Refractory Interactions}

In the study by Scheunis et al., ${ }^{[37]}$ the exposure of magnesia chromia refractories to $\mathrm{PbO}-\mathrm{MgO}-\mathrm{SiO}_{2}$ slag containing $54 \mathrm{~mol}$ pet $\mathrm{PbO}, 41 \mathrm{~mol}$ pet $\mathrm{SiO}_{2}$ and $5 \mathrm{~mol}$ pet $\mathrm{MgO}$ at $1200{ }^{\circ} \mathrm{C}$ was shown, from the reaction between the slag phase and the periclase $(\mathrm{MgO})$ grains, to result in the formation of a secondary phase, olivine (forsterite $\mathrm{Mg}_{2} \mathrm{SiO}_{4}$ ). This was a significant observation since it demonstrated that the open pores within the refractory material could be sealed by the presence of this secondary phase, thus preventing the further penetration of the liquid slag into the refractory. The composition of the liquid formed at the $\mathrm{Mg}_{2} \mathrm{SiO}_{4}$-liquid interface was found to be consistent with the liquidus values indicated by the phase diagram at this temperature by Chen et al. ${ }^{[33]}$

Using the same refractory and slag composition as in Reference 37 but with the imposition of a temperature gradient across the cross-section of the refractory, it was reported in Reference 38 that not only was $\mathrm{Mg}_{2} \mathrm{SiO}_{4}$ formed, but also, in the lower temperature section of the refractory, the melilite phase $[\mathrm{Ca}, \mathrm{Pb}]_{2}[-$ $\mathrm{Fe}, \mathrm{Mg}, \mathrm{Al}][\mathrm{Si}, \mathrm{Al}, \mathrm{Fe}]_{2} \mathrm{O}_{7}$. It might be expected from the results of the present phase equilibrium study (see Figure 3) of the $\mathrm{PbO}-\mathrm{MgO}-\mathrm{SiO}_{2}$ ternary system that the barysilite phase $\mathrm{Pb}_{8} \mathrm{MgSi}_{6} \mathrm{O}_{21}$ would be formed at these temperatures. This difference between the observed and predicted phases could possibly be accounted for by the presence of calcium silicate phases in the original refractory raw materials or calcium oxide used to control the microstructure and phase assemblages during manufacture of the refractory. ${ }^{[1,12]}$ As the slag penetrates into the refractory material and the silica component is removed in the form of the olivine phase, this may lead to the increase in concentrations of calcium oxide and conditions favorable for the formation of the melilite phase. The reaction of the $\mathrm{MgO}$ with the trapped or isolated slag is expected to significantly lower the $\mathrm{SiO}_{2}$ concentration in the residual slag within the refractory; if this reaction goes 


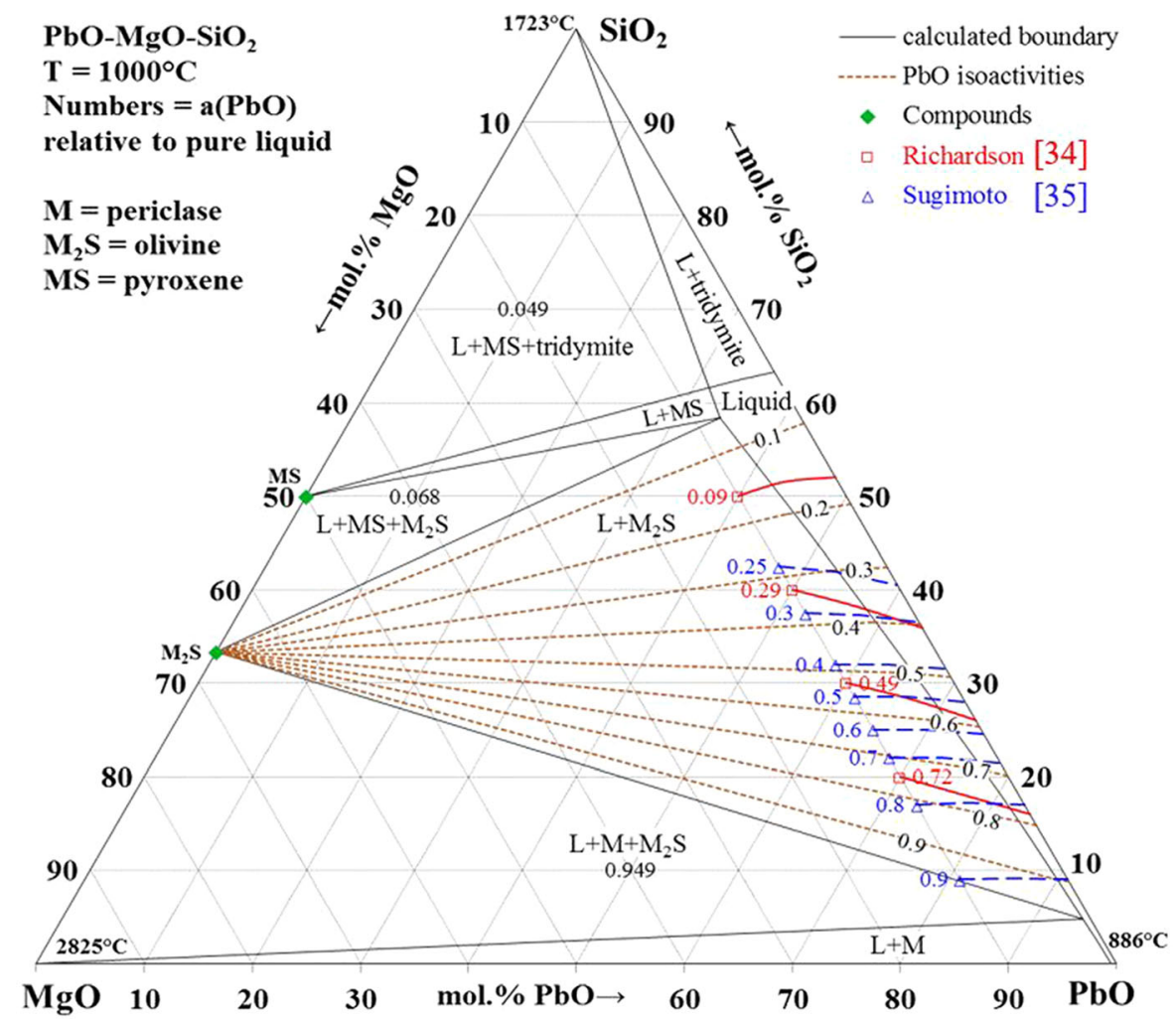

(a)

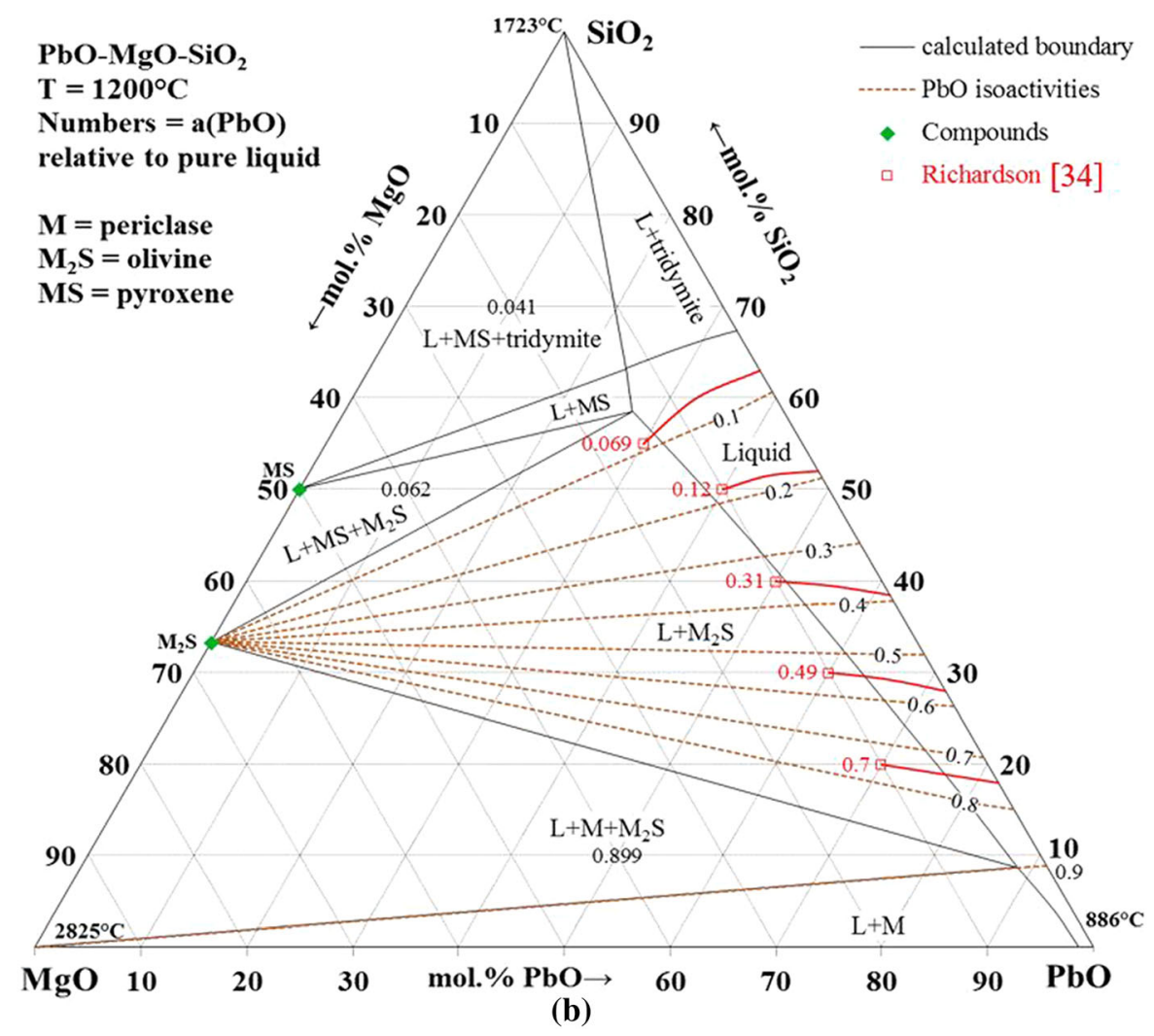

Fig. 5-Activities of $\mathrm{PbO}$ in the $\mathrm{PbO}-\mathrm{MgO}-\mathrm{SiO}_{2}$ system at $(a) 1000{ }^{\circ} \mathrm{C}$ and $(b) 1200{ }^{\circ} \mathrm{C}$ compared to the data by Richardson ${ }^{[34]}$ and Sugimoto ${ }^{[35]}$ 
to the thermodynamic limit, it is predicted (from Figure 3 ) that massicot $(\mathrm{PbO})$ will form. More rapid cooling of the refractory or shorter reaction times may result in incomplete reaction and the formation of the binary lead silicate phases, as indicated in the discussion in Reference 38.

The detailed information on the relative stabilities of the oxide phases through the development of the thermodynamic databases provides important tools with which to analyze the slag-refractory interactions. Examples of application of the methodology and the technique that can be used in the development of self-healing refractories are given in References 4, 66.

\section{SUMMARY}

In the present study of the $\mathrm{PbO}-\mathrm{MgO}-\mathrm{SiO}_{2}$ ternary system, the phase equilibria and liquidus isotherms in the tridymite, cristobalite, olivine (forsterite), pyroxene (protoenstatite), barysilite, massicot and periclase primary phase fields were measured. Liquidus isotherms in the cristobalite and tridymite primary phase field were determined. The isotherms on the liquidus surface in the olivine (forsterite $\mathrm{Mg}_{2} \mathrm{SiO}_{4}$ ) primary phase field at concentrations below approximately 35 mol pct $\mathrm{SiO}_{2}$ and up to $1200{ }^{\circ} \mathrm{C}$ were measured. The boundary lines between the tridymite-pyroxene, pyroxene-olivine and olivine-periclase phases were determined. The equilibria between the cristobalite phase and two-liquid immiscibility region at $1650{ }^{\circ} \mathrm{C}$ was measured. The results were also used for the improvement of the thermodynamic database describing this complex $\mathrm{Pb}$-containing system, and the liquidus for the whole of the $\mathrm{PbO}-\mathrm{MgO}-\mathrm{SiO}_{2}$ ternary system is predicted. The results can also be used to provide a clearer understanding of the chemical reactions occurring between lead-containing melts and refractory materials.

\section{ACKNOWLEDGMENTS}

The authors thank Australian Research Council Linkage program LP180100028 and a consortium of lead producers, Aurubis, Boliden, Kazzinc Ltd. Glencore, Nyrstar, Peñoles and Umicore, for the financial support for this study. The authors thank the staff at the Centre for Microscopy and Microanalysis (CMM), University of Queensland, for technical support.

\section{FUNDING}

Open Access funding enabled and organized by CAUL and its Member Institutions.

\section{CONFLICT OF INTEREST}

On behalf of all authors, the corresponding author states that there is no conflict of interest.

\section{OPEN ACCESS}

This article is licensed under a Creative Commons Attribution 4.0 International License, which permits use, sharing, adaptation, distribution and reproduction in any medium or format, as long as you give appropriate credit to the original author(s) and the source, provide a link to the Creative Commons licence, and indicate if changes were made. The images or other third party material in this article are included in the article's Creative Commons licence, unless indicated otherwise in a credit line to the material. If material is not included in the article's Creative Commons licence and your intended use is not permitted by statutory regulation or exceeds the permitted use, you will need to obtain permission directly from the copyright holder. To view a copy of this licence, visit http://creativec ommons.org/licenses/by/4.0/.

\section{REFERENCES}

1. A.J. Rigby: EPD Congress 1993-Converting, Fire Refin. Cast., TMS-AIME, Denver, Colorado, USA, 1993, pp. 155-68.

2. H. Barthel: Int. Ceram., 1981, vol. 30, pp. 250-55.

3. V. Petkov: Degradation mechanism of copper anode furnace refractory lining, Ph.D. thesis, KU Leuven, Belgium, 2007.

4. A. Fallah Mehrjardi, P.C. Hayes, T. Azekenov, L. Ushkov and E. Jak: 10th Int. Conf. on Molten Slags, Fluxes and Salts, Springer International Publishing, Seattle, Washington, USA, 2016, pp. 1071-76.

5. A. Fallah-Mehrjardi, P.C. Hayes, E. Jak, T. Azekenov and L. Ushkov: 9th Int. Copper Conf., Kobe, Japan, 2016.

6. H. Abdeyazdan, A. Fallah-Mehrjardi, T. Hidayat, M. Shevchenko, P.C. Hayes, and E. Jak: J. Phase Equilib. Diffus., 2020, vol. 41, pp. 44-55.

7. A. Malfliet, S. Lotfian, L. Scheunis, V. Petkov, L. Pandelaers, P.T. Jones, and B. Blanpain: J. Eur. Ceram. Soc., 2014, vol. 34(3), pp. 849-76.

8. E.M. Levin, C.R. Robbins, and H.F. McMurdie: Phase Diagrams for Ceramists, American Ceramic Society, Columbus, 1964.

9. A. Muan and E.F. Osborn: Phase Equilibria Among Oxides in Steelmaking, Addison Wesley Publishing company Inc., Reading, 1965.

10. A.M. Alper, R.C. Doman, R.N. McNally, and H.C. Yeh: Use of Phase Diagrams in Fusion-Cast Refractory Materials Research, Academic, New York, 1970, pp. 117-46.

11. H.W. Kraner: Phase Diagrams., 1970, vol. 2, pp. 67-115.

12. J. White: Phase Diagrams, Materials Science and Technology, Academic, New York, 1970, p. 77.

13. T. Taschler: Tehran Int. Conf. Refract., Tehran, Iran, 2004, pp. 302-20.

14. M. Koeffel and T. Taschler: World Metall. Erzmet., 2006, vol. 59(3), pp. 133-42.

15. D. Gregurek, K. Reinharter, C. Majcenovic, C. Wenzl, and A. Spanring: J. Eur. Ceram. Soc., 2015, vol. 35(6), pp. 1683-98.

16. D. Gregurek, C. Majcenovic, A. Spanring, and M. Kirschen: RHI Bull., 2011, vol. 2, pp. 49-53.

17. J. White: J. Iron Steel Inst., 1962, vol. 200, pp. 611-21.

18. R.F. Geller, A.S. Creamer and E.N. Bunting: Research paper RP705, National Bureau of Standards, 1934, vol. 13, pp. 237-44.

19. U. Kuxmann and P. Fischer: Erzmetall., 1974, vol. 27(11), pp. 533-37.

20. K.A. Krakau, E.J. Mukhin and M.S. Geinrich: Nauk S.S.S.R., Otdel. Khim. Nauk, Acad. Nauk S.S.S.R. i Gosudarst. Ordena Lenina Opticheskii Inst., Sbornik Statei, 1949, pp. 15-38.

21. R.M. Smart and F.P. Glasser: J. Am. Ceram. Soc., 1974, vol. 57(9), pp. $378-82$ 
22. E. Jak, S.A. Decterov, P. Wu, P.C. Hayes, and A.D. Pelton: Metall. Mater. Trans. B., 1997, vol. 28B, pp. 1011-18.

23. M. Shevchenko and E. Jak: J. Am. Ceram. Soc., 2017, vol. 101(1), pp. 458-71.

24. K. Hirota and Y.T. Hasegawa: Bull. Chem. Soc. Jpn., 1981, vol. 54(3), pp. 754-56.

25. J.W. Greig: Am. J. Sci., 1927, vol. 13(73), pp. 1-44.

26. N.L. Bowen and O. Andersen: Am. J. Sci., 1914, vol. 37, pp. 487-500.

27. C.M. Schlaudt and D.M. Roy: J. Am. Ceram. Soc., 1965, vol 48(5), pp. 248-51.

28. Y.I. Ol'shanskii: Dokl. Akad. Nauk SSSR., 1951, vol. 76, pp. 93-96.

29. V.B. Hageman and H.A. Oonk: Phys. Chem. Glasses., 1986, vol. 27(5), pp. 194-98.

30. P. Wu, G. Eriksson, A.D. Pelton, and M. Blander: ISIJ Int., 1993, vol. 33(1), pp. 26-35.

31. M. Hillert and X. Wang: Calphad., 1989, vol. 13(3), pp. 253-66.

32. J.F. Argyle and F.A. Hummel: Glass Industry, 1965, vol. 46(10;12), pp. 583-87; pp. 627-28; pp. 710-18.

33. S. Chen, B. Zhao, E. Jak, and P.C. Hayes: Metall. Mater. Trans. B., 2001, vol. 32B, pp. 11-16.

34. F.D. Richardson and T.C.M. Pillay: Trans. Inst. Min. Metall., 1957, vol. 66, pp. 309-30.

35. E. Sugimoto and Z. Kozuka: Trans. Jpn. Inst. Metall., 1978, vol. 19(5), pp. 275-80

36. Y. Ouchi and E. Kato: Can. Metall. Q., 1983, vol. 22(1), pp. 45-51.

37. L. Scheunis, A. Fallah Mehrjardi, M. Campforts, P.T. Jones, B. Blanpain, and E. Jak: J. Eur. Ceram. Soc., 2014, vol. 34(6), pp. 1599-1610.

38. L. Scheunis, A. Fallah-Mehrjardi, M. Campforts, P.T. Jones, B. Blanpain, A. Malfliet, and E. Jak: J. Eur. Ceram. Soc., 2015, vol. 35(10), pp. 2933-42.

39. E. Jak, M. Shevchenko, D. Shishin, T. Hidayat and P.C. Hayes: 9th International Symposium on Lead and Zinc Processing. The Minerals, Metals \& Materials Series. Springer, Cham, San Diego, California, USA, 2020, pp. 337-49.

40. E. Jak, T. Hidayat, D. Shishin, V. Prostakova, M. Shevchenko and P.C. Hayes: 58th Annual Conference of Metallurgists Copper, MetSoc, Vancouver, Canada, 2019, p. 595879.

41. D. Shishin, P.C. Hayes and E. Jak: Extraction 2018, Springer, Ottawa, 2018, pp. 853-68

42. D. Shishin, P.C. Hayes and E. Jak: 58th Annual Conference of Metallurgists Copper, MetSoc, Vancouver, Canada, 2019, p. 594861.

43. C.W. Bale, E. Belisle, P. Chartrand, S.A. Decterov, G. Eriksson, A.E. Gheribi, K. Hack, I.H. Jung, Y.B. Kang, J. Melancon, A.D.
Pelton, S. Petersen, C. Robelin, J. Sangster, P. Spencer, and M.A. Van Ende: Calphad., 2016, vol. 54, pp. 35-53.

44. www. Factsage.com, Montreal, 2019.

45. T. Hidayat, H.M. Henao, P.C. Hayes, and E. Jak: Metall. Mater. Trans. B., 2012, vol. 43B, pp. 1034-45.

46. E. Jak, P.C. Hayes, and H.-G. Lee: Korean J. Miner. Mater. Inst., 1995, vol. 1(1), pp. 1-8.

47. E. Jak: 9th Intl. Conf. on Molten Slags, Fluxes and Salts, The Chinese Society for Metals, Beijing, China, 2012, pp. 1-28, w77.

48. A.E. Grau and C.R. Masson: Can. Metall. Q., 1977, vol. 16, pp. $82-87$.

49. M. Shevchenko, T. Hidayat, P. Hayes and E. Jak: 10th Intl. Conf. on Molten Slags, Fluxes and Salts, Springer, Seattle, Washington, 2016, pp. 1221-28.

50. S. Nikolic, P.C. Hayes, and E. Jak: Metall. Mater. Trans. B., 2009, vol. 40B, pp. 892-99.

51. I.-H. Jung, S.A. Decterov, and A.D. Pelton: Metall Mater. Trans. B., 2004, vol. 38B, pp. 877-89.

52. M. Shevchenko and E. Jak: Calphad., 2019, vol. 64, pp. 318-26.

53. A.D. Pelton, S.A. Decterov, G. Eriksson, C. Robelin, and Y. Dessureault: Metall. Mater. Trans. B., 2000, vol. 31, pp. 651-59.

54. S. Petersen and K. Hack: Int. J. Mater. Res., 2007, vol. 98(10), pp. 935-45.

55. D. Shishin: Development of a thermodynamic database for copper smelting and converting, Ph.D. thesis, Ecole Polytechnique of Montreal, Canada, 2013.

56. A.D. Pelton and P. Chartrand: Metall. Mater. Trans. A., 2001, vol. 32B, pp. 1355-60.

57. P. Chartrand and A.D. Pelton: J. Phase Equilib., 2000, vol. 21(2), pp. $141-47$.

58. A.D. Pelton: Calphad., 2001, vol. 25(2), pp. 319-28.

59. P.J. Lajzerowicz: Acta Crystallogr., 1965, vol. 20, pp. 357-63.

60. D. Bordeaux and J. Lajzerowicz: Bull. Soc. Fr. Miner. Cristallogr., 1969, vol. 92(4), pp. 383-85.

61. A.B. Harnik: Am. Miner., 1972, vol. 57, pp. 277-81.

62. U. Schmidt, K.H. Breuer, and W. Eysel: Neues Jahrb. Miner. Monatsh., 1983, vol. 5, pp. 227-35.

63. J.W. Greig: Am. J. Sci., 1927, vol. 13(74), pp. 133-54

64. P. Richet, F. Leclerc, and L. Benoist: Geophys. Res. Lett., 1993, vol. 20(16), pp. 1675-78.

65. J. Jung: J. Therm Anal., 1992, vol. 38(4), pp. 873-78.

66. A. Fallah Mehrjardi, P.C. Hayes, T. Azekenov, L. Ushkov and E. Jak: 15th Biennial Unified International Technical Conference on Refractories (UNITECR), Santiago, Chile, 2017.

Publisher's Note Springer Nature remains neutral with regard to jurisdictional claims in published maps and institutional affiliations. 